\title{
Longitudinality in Primary Health Care: a comparison between care models
}

\author{
A longitudinalidade na Atenção Primária à Saúde: comparação entre modelos assistenciais \\ La longitudinalidad en la Atención Primaria a la Salud: comparación entre modelos asistenciales
}

\section{Marciane Kessler', Suzinara Beatriz Soares de Lima', Teresinha Heck Weiller', Luís Felipe Dias Lopes', Lucimare Ferraz", Elaine Thumé'II}

' Universidade Federal de Santa Maria. Santa Maria, Rio Grande do Sul, Brazil.

"Universidade do Estado de Santa Catarina. Chapecó, Santa Catarina, Brazil.

"' Universidade Federal de Pelotas. Pelotas, Rio Grande do Sul, Brazil.

\begin{abstract}
How to cite this article:
Kessler M, Lima SBS, Weiller TH, Lopes LFD, Ferraz L, Thumé E. Longitudinality in Primary Health Care: a comparison between care models. Rev Bras Enferm [Internet]. 2018;71(3):1063-71. DOI: http://dx.doi.org/10.1590/0034-7167-2017-0014
\end{abstract}

Submission: 02-20-2017_Approval: 05-31-2017

\begin{abstract}
Objective: to evaluate the attribute longitudinality in different models of assistance in Primary Health Care and observe its association with demographic, socioeconomic and health care characteristics. Method: a cross-sectional study, carried out in 2015 with 1076 adult users of primary care services in the 32 cities of the 4th Regional Health Care Core of Rio Grande do Sul State. The Primary Care Assessment Tool was used with definition of low $(<6.6)$ or high $(\geq 6.6)$ score for longitudinality. The association with independent variables was observed through the Poisson regression. Results: the attribute was better assessed in the Family Health Strategy and associate with age, housing health region and care model. Conclusion: the study points out the Family Health Strategy as a promoter of longitudinal care, and so, it suggests the expansion of this assistance model coverage for quality improvement in health care.
\end{abstract}

Descriptors: Primary Health Care; Continuity of Patient Care; Health Services Evaluation; Cross-sectional Studies; Nursing.

\section{RESUMO}

Objetivo: avaliar o atributo longitudinalidade nos diferentes modelos assistenciais na Atenção Primária à Saúde e verificar sua associação com as características demográficas, socioeconômicas e de contexto de Atenção à Saúde. Método: estudo transversal, realizado em 2015 com 1076 usuários adultos dos serviços de atenção primária nos 32 municípios da $4^{a}$ Coordenadoria Regional de Saúde do Rio Grande do Sul. Foi utilizado o Primary Care Assessment Tool com definição de baixo $(<6,6)$ ou alto escore $(\geq 6,6)$ para longitudinalidade. A associação com variáveis independentes foi verificada através da regressão de Poisson. Resultados: o atributo foi melhor avaliado na Estratégia de Saúde da Família e associado à idade, região de saúde de moradia e modelo de atenção. Conclusão: o estudo destaca a Estratégia de Saúde da Família como promotora do cuidado longitudinal, e assim, sugere-se a ampliação da cobertura deste modelo assistencial para a melhoria da qualidade na Atenção à Saúde.

Descritores: Atenção Primária à Saúde; Continuidade da Assistência ao Paciente; Avaliação de Serviços de Saúde; Estudos Transversais; Enfermagem.

\section{RESUMEN}

Objetivo: evaluar el atributo lingitudinalidad en los diferentes modelos asistenciales de la Atención Primaria a la Salud y verificar su asociación con las características demográficas, socioeconómicas y de contexto de Atención a la Salud. Método: estudio transversal, realizado en 2015 con 1076 usuarios adultos de los servicios de atención primaria en los 32 municipios de la $4^{\text {a }}$ Coordinadora Regional de Salud del Estado del Rio Grande do Sul. Se utilizó el Primary Care Assessment Tool con definición de bajo $(<6,6)$ o alto puntuación $(\geq 6,6)$ para longitudinalidad. La asociación con variables independientes fue comprobada por medio de la Regresión de Poisson. Resultados: el atributo fue mejor evaluado en la Estrategia de Salud de la Familia y asociado a la edad, la región de salud de vivienda y modelo de atención. Conclusión: el estudio destaca la Estrategia 
de la Salud de la Familia como promotora del cuidado longitudinal, y así, se sugiere la ampliación de la cobertura de este modelo asistencial para la mejora de calidad en la Atención a la Salud.

Descriptores: Atención Primaria a la Salud; Continuidad de la Asistencia al Paciente; Evaluación de los Servicios de Salud; Estudios Transversales; Enfermería.

\section{CORRESPONDING AUTHOR Marciane Kessler E-mail: marciane.kessler@hotmail.com}

\section{INTRODUCTION}

In the Unified Health System (SUS) level, Primary Health Care $(\mathrm{PHC})$ is essential to build a care model in the assurance of positive results to health in an effective, efficient and fair way ${ }^{(1)}$. This level of care defined by a set of fundamental values and principles of health system have as essential attributes: access of first contact, longitudinality, full care and care coordination ${ }^{(2)}$. In addition, it considers the family-centered care, the community orientation and the cultural competence as derived attributes ${ }^{(2)}$.

PHC attributes are important quality indicators of this care lev$\mathrm{el}^{(3)}$, accepted by experts and widely spread in Brazil(4-6). In this context, the attribute longitudinality stands out, which is made through the existence of a usual source of care and its use over time, assuming that the relationship between users and professionals should reflect interpersonal confidence and a lasting bond ${ }^{(2,6)}$.

The literature points out the potential of longitudinality as a possibility to know the user, its social context, life habits and health problems, leading to proper and remedial interventions. As such, would provide a full care, with actions of health promotion and diseases prevention, as well as use reduction of high complexity services with costs reduction in health sector ${ }^{(2,7)}$.

However, obstacles in the organization and management of health services may make the longitudinal care more difficult. For example, workload and lack of professionals, dissatisfaction and bad experiences of users with the service and the interpersonal relationship ${ }^{(8)}$. It can also be pointed out the professional training and performance unrelated to reality of living and health conditions of the population, the lack of reception, the fragmentation of care $^{(9)}$ and healing care model, as factors that disadvantage the longitudinality.

In the world scenario, the PHC was adopted from many organizational strategies and care model $s^{(1)}$. In Brazil, the expansion and reorientation of PHC occurs especially from the Family Health Strategy $(\mathrm{FHS})^{(10)}$, defined by a set of actions and services designed to identify the population needs as of the bond between users and professionals, prioritizing health promotion actions, in an integral and continuous way ${ }^{(9)}$. The FHS recommends a multiprofessional, delimitation of coverage area, with postscript and observation of the resident population in the area of operation ${ }^{(10-11)}$.

However, Brazil has a previous history in offering health services that contains other PHC care models, persisting today the traditional model aimed at the biomedical model, with a team containing expert doctors; the assisted demand is spontaneous and without users postscript ${ }^{(11)}$. In addition, it may be observed health services performed by a FHS team and a traditional model team or expert doctors, forming a mixed care model.

Studies has presented results of more positives services performance with the FHS compared to those of traditional primary care $^{(12-13)}$. Other researches show the contribution of the FHS expansion and consolidation to reduce hospitalization due to conditions sensitive to primary care and the PHC quality and performance improvement ${ }^{(14-15)}$. Similarly, care models influence in the creation of bond between users and professionals and define longitudinal care. Regardless of the care model, it is essential to have the prerogatives of the National Policy of Basic Care ${ }^{(10)}$ in the health care network organization, thereby ensuring monitoring of users, continuity and effectiveness of care.

Considering the diversity of care models, it becomes convenient to evaluate the longitudinality performance. Furthermore, quantitative studies that evaluate isolation of a PHC attribute and the associated variables are scarce.

\section{OBJECTIVE}

To evaluate the attribute longitudinality in different care models in Primary Health Care and to observe its relation to demographic, socioeconomic and health care context characteristics.

\section{METHODS}

\section{Ethical aspects}

The research is part of a matrix project, submitted and approved by Research Ethics Committees of Universidade Federal de Santa Maria (UFSM), according to precepts of Resolution $466 / 2012$. The participants were informed about the objectives of the survey and asked to read and sign an informed consent form.

\section{Design, study location and period}

It is a cross-sectional study, carried out in the PHC network of the 32 cities of the 4th Regional Health Care Core (RHCC) of Rio Grande do Sul State, from February to June of 2015. The PHC services network were consisting of health units with a traditional care model, a FHS or a mixed care model. In Brazil, primary health care and basic health care are considered as being equivalent terms ${ }^{(10)}$.

The 4th RHCC of Rio Grande do Sul State comprises two health regions called Verdes Campos and Entre Rios. The former consists of 21cities and its headquarters is located in Santa Maria, Rio Grande do Sul State. In the year of the study, had 89 basic health unit (UBS) with 52 FHS deployed. The latter consists of 11 cities and its headquarters is located in Santiago, also in Rio Grande do Sul State. In the same year had 49 basic health unit (UBS) with 32 FHS deployed ${ }^{(16)}$. Thus, it summed $138 \mathrm{PHC}$ establishments in these 32 cities, of which $60.87 \%$ had a FHS team, coexisting in the same physical space, in some, a traditional model service. The 4 th CRS is located in the central region 
of the Rio Grande do Sul State and its population, in 2014, is estimated at 559,498 thousand inhabitants ${ }^{(17)}$.

\section{Samples, inclusion and exclusion criteria}

The population that is being studied consists of PHC adult users of the 4th CRS cities. Therefore, the sample size definition was based on this population $(406,741)$, by the following sample calculation: $n=Z^{2}$ a/2.p.q. $N / \mathrm{e}^{2}(\mathrm{~N}-1)+Z^{2} \mathrm{a} / 2 . p . q$, in which " $n$ " is the sample size; " $Z$ ' ( $(\mathrm{a} / 2)$ " is 1.96 (tabled value), " $p$ " is 0.5 (estimated percentage); " $q$ " is 0.5 (proportional population of individual that do not belong to the category which we are interested to study $(\mathrm{q}=1-\mathrm{p})$; " $\mathrm{N}$ " is the population size $(406,741) ; " \mathrm{e}$ " is $0.03(3 \%)$ (sample error); and " $\mathrm{a}$ " is 0.05 (trust level). Thereby, a representative sample was obtained ( $\mathrm{n}=$ $1,065)$, being interviewed 1,076 users.

The sample was proportional to each city. Health establishments were selected according to the size of the basic care network and easy transportation for the interviewers. Users were selected by convenience sampling, concerning about locating PHC users in the 32 cities, depending on the sample size, as well as in the different models of care located in each city. The selected users were those who were at the health unit facilities. The eligibility criteria of individuals were: to be a user of the unit and be $\geq 18$ years old at the day of interview. The excluded users were the adults in the access to the PHC services and with no condition of cognitive health to answer to the research tool.

\section{Study protocol}

Data was collected by graduate students of the postgraduate program in nursing of the UFSM, unrelated to health services. The data were collected with tablets, using the program called Epi Info version 7.0. The research tool used was the Primary Care Assessment Tool (PCATool), adult version, validated in Brazil in 2006-2007(5), applied in an interview format.

The outcome studied was the longitudinality (care process) in the APS services (dependent variable) and the degree of affiliation (DA), considered structural, was used to evaluate the attribute range. The longitudinality score was set by arithmetic average of the 14 items (questions) listed on the instrument, and the answers on Likert scale: "absolutely not" (value $=1$ ), "probably not" (value $=2$ ), "probably yes" (value $=3$ ) and "definitely yes" (value =4). Once the sum of the answers "I don't know/don't remember" (value $=9$ ) reached $50 \%$ or more of the total of items for longitudinality evaluation, the questionnaire was excluded; otherwise, these answers were considered "probably not" ${ }^{\text {"(4). In }}$ this process was registered a loss of nine questionnaires, resulting in a final sample of 1,067 adult users.

The degree of affiliation was defined based on application of three questions with dichotomous answers (yes or no): "There is a professional or healthcare service where you usually go when you get sick or need and advice about your health?; There is a professional or healthcare service that know you better as a person?; There is a professional or healthcare service more responsible for your health care?". In the case of positive answers, the service or professional name was asked. The answers relating to specialized or particular services were considered "no" to the PHC. The score of the degree of affiliation was defined from the following algorithm: "all the answers No to the $\mathrm{PHC}^{\prime}=\mathrm{DA} 1$; "one, two, or three answers Yes, but relating to different services of $\mathrm{PHC}^{\prime \prime}=\mathrm{DA} 2$; "two answers Yes and equal to the $\mathrm{PHC}^{\prime \prime}=3$ $\mathrm{DA}$; "all the answers Yes to the PHC" $=\mathrm{DA} 4^{(4)}$.

From this, the score of the degree of affiliation and longitudinality were turned into a continuous quantitative scale from 0 to 10, using the following formula: (obtained score - 1)*10/4-1. The values $<6.6$ were considered low scores (unsatisfactory) and the values $\geq 6.6$ high scores (satisfactory) ${ }^{(4)}$.

Demographic, socioeconomic and health context variables were (independent variables): gender (male and female), age group (18 to 38,39 to 59 and 60 to 91 years old), education ( $\leq 8$ years and $>8$ years), color/ethnicity self-referred (white and brown/black/yellow/indigenous), marital status (with and without companion), children (yes and no), income ( $\leq$ two salaries and > two salaries), formal job (yes and no), private health insurance (yes and no), transport used to go to the health units (on foot and bicycle/car/public transport/ school transport/own transport), health region (Verdes Campos e Entre Rios) and the PHC model (UBST, FHS and UBSM).

\section{Analysis of results and statistics}

Data were assessed by the program Statistical Package for the Social Sciences (SPSS) version 16.0 for Windows. The normality distribution of variables was evaluated by the Shapiro Wilk test. The reliability analysis of the instrument PCATool made by means of $\alpha$ of Cronbach considering the value $\geq 0.70$ as reliable.

The qualitative variables were expressed as absolute and relative frequencies and quantitative variables as medians, medium and standard error (SE), with the confidence interval (Cl) of $95 \%$. To compare proportions, was applied the Chisquare test, as needed. To compare attribute average scores, according to the care model, it was used the Kruskal-Wallis test and then it was used the Post Hoc Dunn test to identify which of the pairs of groups differ, being "a" different from "b" and both different from " $c$ ". For all the statistical analysis, it was considered a significance level of $5 \%(p<0.05)$.

To observe the variables related to the high score, it was used the Poisson regression with robust variance, being estimated the Prevalence Ratios (PR) and their respective Confidence Interval $(\mathrm{Cl} 95 \%)$. In the crude and adjusted analysis were included independent variables related to the high score of the longitudinality, with value of $p<0.15$.

\section{RESULTS}

In regard to characterization, the participants were mostly female $(76.3 \%)$, aged from 18 to 38 years old $(45.8 \%)$, white $(69.6 \%)$, with children $(85.2 \%)$, with eight years of schooling or less $(57.5 \%)$, living with companion $(62.2 \%)$, without formal job $(73.0 \%)$, with income of two minimum monthly wages or less $(76.9 \%)$, and with no health insurance $(74.1 \%)$. With respect to transport used for going to the PHC services, $59.6 \%$ reported moving on foot. The highest percentage of interviewed users was from the health region Verdes Campos $(76.9 \%)$, the FHS users $(42.2 \%)$ and the traditional health model $(41.9 \%)$. 
Table 1 -

Demographic and socioeconomic characteristics of the Primary Health Care users from cities that integrate the 4th Regional Health Care Core, in Santa Maria, Rio Grande do Sul State, Brazil, 2015 ( N=1067)

\begin{tabular}{|c|c|c|}
\hline Variable & n (1067) & $\%(100.0)$ \\
\hline \multicolumn{3}{|l|}{ Gender } \\
\hline Male & 253 & 23.7 \\
\hline Female & 814 & 76.3 \\
\hline \multicolumn{3}{|l|}{ Age Group* } \\
\hline $18-38$ & 485 & 45.8 \\
\hline $39-59$ & 401 & 37.9 \\
\hline $60-91$ & 173 & 16.3 \\
\hline \multicolumn{3}{|l|}{ Color/Ethnicity* } \\
\hline White & 740 & 69.6 \\
\hline Brown/black/yellow/indigenous & 323 & 30.4 \\
\hline \multicolumn{3}{|l|}{ Children* } \\
\hline Yes & 907 & 85.2 \\
\hline No & 157 & 14.8 \\
\hline \multicolumn{3}{|l|}{ Education* } \\
\hline$\leq 8$ years old & 611 & 57.5 \\
\hline$>8$ years old & 452 & 42.5 \\
\hline \multicolumn{3}{|l|}{ Marital Situation* } \\
\hline With companion & 661 & 62.2 \\
\hline Without companion & 402 & 37.8 \\
\hline
\end{tabular}

Table 1 (concluded)

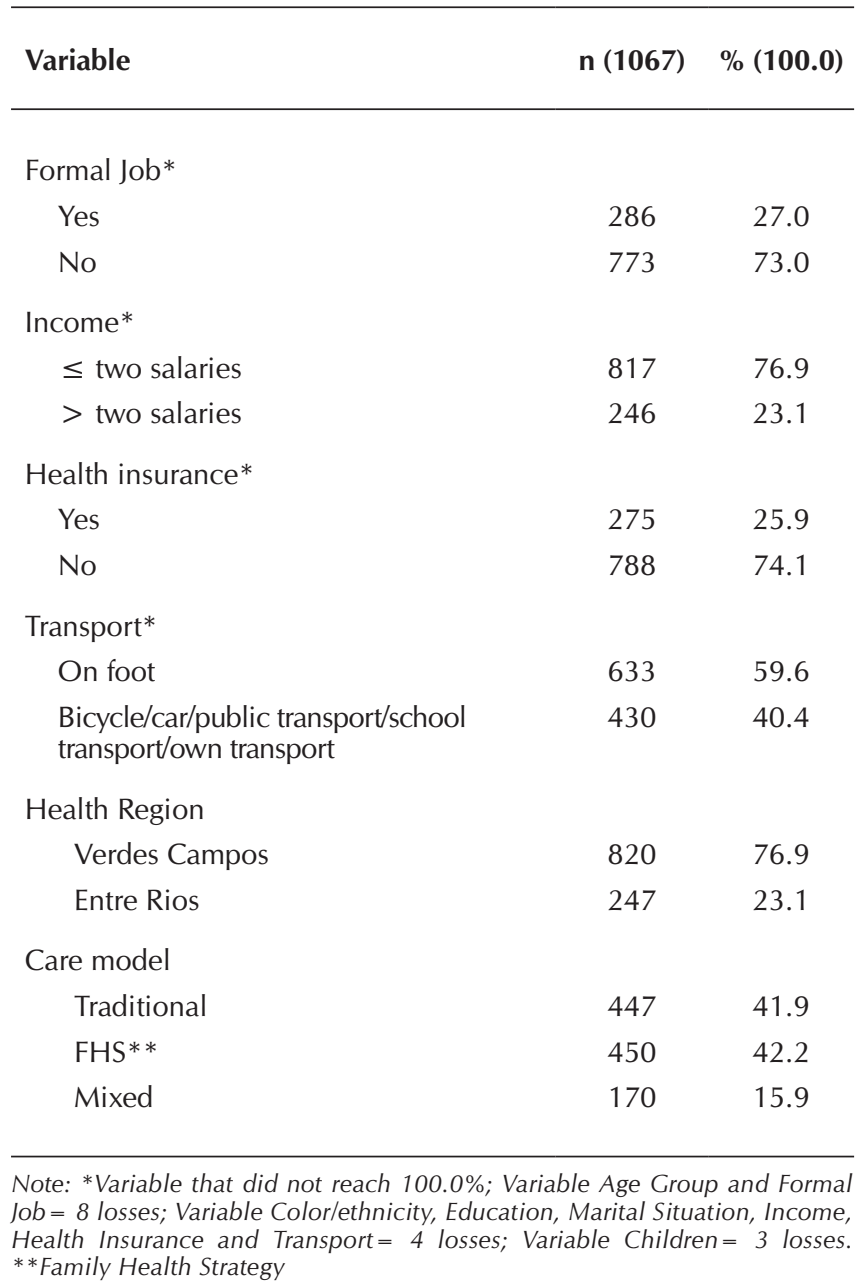

Table 2 - Comparison of the affiliation degree scores and the longitudinality of the Primary Health Care between the care models, given by the users, in the cities of the 4th Regional Health Care Core, in Santa Maria, Rio Grande do Sul State, Brazil, $2015(\mathrm{~N}=1067)$

\begin{tabular}{|c|c|c|c|c|c|c|}
\hline \multirow{2}{*}{ Care model } & \multicolumn{6}{|c|}{ Degree of Affiliation (0-10) } \\
\hline & Standard score & Standard error & Median & Minimum & Maximum & $p^{*}$ \\
\hline Traditional & $8.8^{\mathrm{a}}$ & $8.6-9.0$ & 10.0 & 0.0 & 10.0 & 0.005 \\
\hline FHS** & $8.5^{b}$ & $8.3-8.7$ & 10.0 & 0.0 & 10.0 & \\
\hline Mixed & $8.4^{\mathrm{c}}$ & $8.0-8.7$ & 10.0 & 0.0 & 10.0 & \\
\hline
\end{tabular}

Longitudinality score (0-10)

\begin{tabular}{|c|c|c|c|c|c|c|}
\hline \multirow{2}{*}{ Care model } & \\
\hline & Standard score & Standard error & Median & Minimum & Maximum & $p^{*}$ \\
\hline Traditional & $6.1^{b}$ & $5.9-6.2$ & 6.2 & 0.5 & 10.0 & $<0.001$ \\
\hline FHS $* *$ & $6.9^{a}$ & $6.7-7.1$ & 7.1 & 0.7 & 10.0 & \\
\hline Mixed & $5.8^{c}$ & $5.5-6.2$ & 5.7 & 0.2 & 10.0 & \\
\hline
\end{tabular}

Note: *Value of p: Kruskal-Wallis Test and Dunn Test $(a, b, c)-$ Statistically considerable difference $(p<0.05) . * *$ Family Health Strategy 
Table 3 - Distribution of the outcome according to demographic, socioeconomic and health context characteristics in the cities of the 4th Regional Health Care Core, in Santa Maria, Rio Grande do Sul State, Brazil, $2015(\mathrm{~N}=1067)$

\begin{tabular}{|c|c|c|c|c|c|}
\hline \multirow{3}{*}{ Variables } & \multicolumn{5}{|c|}{ Longitudinality } \\
\hline & \multicolumn{2}{|c|}{$\begin{array}{c}\text { Low score } \\
\quad(<\mathbf{6 . 6})\end{array}$} & \multicolumn{2}{|c|}{$\begin{array}{l}\text { High score } \\
(\geq 6.6)\end{array}$} & \multirow[t]{2}{*}{$p^{*}$} \\
\hline & $\mathbf{n}$ & $\%$ & $\mathbf{n}$ & $\%$ & \\
\hline Gender & & & & & 0.695 \\
\hline Male & 131 & 24.2 & 122 & 23.2 & \\
\hline Female & 410 & 75.8 & 404 & 76.8 & \\
\hline Age Group & & & & & $<0.001$ \\
\hline $18-38$ & 290 & 54.5 & 195 & 37.0 & \\
\hline $39-59$ & 176 & 33.1 & 225 & 42.7 & \\
\hline $60-91$ & 66 & 12.4 & 107 & 20.3 & \\
\hline Color/Ethnicity & & & & & 0.490 \\
\hline White & 379 & 70.6 & 361 & 68.6 & \\
\hline Brown/black/yellow/indigenous & 158 & 29.4 & 165 & 31.4 & \\
\hline Children & & & & & 0.425 \\
\hline Yes & 454 & 84.4 & 453 & 86.1 & \\
\hline No & 84 & 15.6 & 73 & 13.9 & \\
\hline Education & & & & & $<0.001$ \\
\hline$\leq 8$ years old & 274 & 51.0 & 337 & 64.1 & \\
\hline$>8$ years old & 263 & 49.0 & 189 & 35.9 & \\
\hline Marital Situation & & & & & 0.370 \\
\hline With companion & 341 & 63.5 & 320 & 60.8 & \\
\hline Without companion & 196 & 36.5 & 206 & 39.2 & \\
\hline
\end{tabular}

To be continued

In this study, users of the traditional model presented the highest score for degree of affiliation with health service $(8.81$; IC95\%: 8.58-9.04). However, in all the PHC models, the users presented high score with a statistically considerable difference $(p=0.005)$ among the three services (Table 2).

Concerning PHC longitudinality, in which is evaluated the relationship between user and professional, the users of FHS obtained a high score $(6.9 ; \mathrm{IC} 95 \%$ : 6.7-7.1) and considerably higher $(p=<0.001)$ compared to the others care models that present low score. Nevertheless, the score in the traditional model is considerably higher than those in the mixed model of care, although it does not reach the cut-off point (6.6). The trust evaluation of the attribute results by $\alpha$ of Cronbach was considered suitable (0.818).
Table 3 (concluded)

\begin{tabular}{|c|c|c|c|c|c|}
\hline \multirow{3}{*}{ Variables } & \multicolumn{5}{|c|}{ Longitudinality } \\
\hline & \multicolumn{2}{|c|}{$\begin{array}{c}\text { Low score } \\
(<6.6)\end{array}$} & \multicolumn{2}{|c|}{$\begin{array}{l}\text { High score } \\
(\geq 6.6)\end{array}$} & \multirow[t]{2}{*}{$p^{*}$} \\
\hline & $\mathbf{n}$ & $\%$ & $\mathbf{n}$ & $\%$ & \\
\hline Formal Job & & & & & 0.002 \\
\hline Yes & 167 & 31.1 & 119 & 22.8 & \\
\hline No & 370 & 68.9 & 403 & 77.2 & \\
\hline Income & & & & & 0.101 \\
\hline$\leq$ two salaries & 403 & 74.8 & 414 & 79.0 & \\
\hline$>$ two salaries & 136 & 25.2 & 110 & 21.0 & \\
\hline Health insurance & & & & & 0.088 \\
\hline Yes & 127 & 23.6 & 148 & 28.2 & \\
\hline No & 411 & 76.4 & 377 & 71.8 & \\
\hline Transport & & & & & 0.514 \\
\hline On foot & 325 & 60.5 & 308 & 58.6 & \\
\hline $\begin{array}{l}\text { Bicycle/car/public transport/ } \\
\text { school transport/ } \\
\text { own transport }\end{array}$ & 212 & 39.5 & 218 & 41.4 & \\
\hline Health Region & & & & & $<0.001$ \\
\hline Verdes Campos & 459 & 84.8 & 361 & 68.6 & \\
\hline Entre Rios & 82 & 15.2 & 165 & 31.4 & \\
\hline Care model & & & & & $<0.001$ \\
\hline Traditional & 265 & 49.2 & 182 & 34.5 & \\
\hline FHS** & 175 & 32.1 & 275 & 52.4 & \\
\hline Mixed & 101 & 18.7 & 69 & 13.1 & \\
\hline
\end{tabular}

Note: Absolute frequency ( $n)$ and relative frequency $(\%) ; *$ Value of $p$ : Chi-square Test. **Family Health Strategy
Table 4 - Crude and adjusted regression for the high score of longitudinality of the Primary Health Care, given by users of the cities of the 4th Regional Health Care Core, in Santa Maria, Rio Grande do Sul State, Brazil, 2015

\begin{tabular}{|c|c|c|c|c|c|c|}
\hline \multirow{2}{*}{ Variables } & \multicolumn{5}{|c|}{ High score of Longitudinality $(0-10)$} & \multirow[b]{2}{*}{$p^{*}$} \\
\hline & PRcrude $^{\#}$ & $\mathrm{Cl} 95 \%+$ & $p^{*}$ & PRadjusted¥ & $\mathrm{Cl} 95 \% \dagger$ & \\
\hline \multicolumn{7}{|l|}{ Age (years) } \\
\hline 60 to 91 & 1.10 & $1.05-1.16$ & $<0.001$ & 1.06 & $1.01-1.11$ & 0.010 \\
\hline 18 to 59 & 1.00 & & & 1.00 & & \\
\hline \multicolumn{7}{|l|}{ Education } \\
\hline$\leq 8$ years old & 1.09 & $1.05-1.14$ & $<0.001$ & 1.05 & $1.00-1.11$ & 0.057 \\
\hline$>8$ years old & 1.00 & & & 1.00 & & \\
\hline \multicolumn{7}{|l|}{ Formal Job } \\
\hline No & 1.07 & $1.03-1.13$ & 0.003 & 1.04 & $0.99-1.09$ & 1.128 \\
\hline Yes & 1.00 & & & 1.00 & & \\
\hline \multicolumn{7}{|l|}{ Income } \\
\hline$\leq$ two salaries & 1.04 & $0.99-1.09$ & 1.040 & 1.01 & $0.96-1.06$ & 0.854 \\
\hline$>$ two salaries & 1.00 & & & 1.00 & & \\
\hline
\end{tabular}


Table 4 (concluded)

\begin{tabular}{|c|c|c|c|c|c|c|}
\hline \multirow[b]{2}{*}{ Variables } & \multicolumn{5}{|c|}{ High score of Longitudinality $(0-10)$} & \multirow[b]{2}{*}{$p^{*}$} \\
\hline & PRcrude ${ }^{\#}$ & Cl 95\% $†$ & $\boldsymbol{p}^{*}$ & PRadjusted $\neq$ & $\mathrm{Cl}$ 95\% & \\
\hline \multicolumn{7}{|l|}{ Health insurance } \\
\hline Yes & 1.04 & $1.00-1.09$ & 0.084 & 1.04 & $0.99-1.09$ & 0.091 \\
\hline No & 1.00 & & & 1.00 & & \\
\hline \multicolumn{7}{|l|}{ Health Region } \\
\hline Entre Rios & 1.16 & $1.11-1.21$ & $<0.001$ & 1.10 & $1.05-1.15$ & $<0.001$ \\
\hline Verdes Campos & 1.00 & & & 1.00 & & \\
\hline \multicolumn{7}{|l|}{ Care model } \\
\hline $\mathrm{FHS}^{* *}$ & 1.15 & $1.10-1.19$ & $<0.001$ & 1.11 & $1.06-1.16$ & $<0.001$ \\
\hline Traditional/Mixed & 1.00 & & & 1.00 & & \\
\hline
\end{tabular}

over time. This result was not observed between the users in the other care models (traditional and mixed). However, the score obtained by the FHS is still far from the maximum score, reinforcing the need to invest in training, in professionals fixation and in continuing education in the cities and local health services.

The results of this study are similar to those found in researches conducted in the PHC with adult users from a city of Minas Gerais State $^{(18)}$ and with healthcare providers in the city of Curitiba, Paraná State ${ }^{(13)}$ and in the city of Santa Maria, Rio Grande do Sul State $^{(19)}$, in which the FHS showed satisfactory score for the longitudinality in comparison with the other PHC care models. In research-
The Table 3 show the profile variables of the participants of the study with the evaluation of high and low score for longitudinality. In regard to this attribute score, it was clear that a statistically considerable difference between the obtained prevalence among age groups $(p=<0.001)$, education $(p=<0.001)$, kind of job $(p=0.002)$, health region $(p=<0.001)$ and Health Care models $(p=<0.001)$.

In Table 4, are presented the crude and adjusted analyses between the PHC longitudinality scores of the of the 4th RHCC/ Rio Grande do Sul State, given by adult users of this service.

The analysis of crude regression demonstrated that, being elderly, having 8 years or less of education, no formal job, living in the health region Entre Rios and being FHS user is not related to the high score of longitudinality. After adjustments, it was proved to be associated with high score: being 60 years old or older $(\mathrm{PR}=1.060 ; \mathrm{Cl95} \%=1.014-1.108)$, living in the health region Entre Rios ( $P R=1.098 ; C 195 \%=1.049-1.149)$ and being FHS care model user $(\mathrm{PR}=1.107 ; \mathrm{Cl} 95 \%=1.061-1.155)$.

\section{DISCUSSION}

In the evaluation of longitudinality was observed that the users show high degree of affiliation to the PHC services, regardless of care model. The prevalence for high score of longitudinality were higher between users served by the FHS and kept statistically significant association after adjustment for the respondents age, health region and care model.

In the analysis of users' profile, it is pointed out the socioeconomic vulnerability, expressed by the high prevalence of poor education, informal job and monthly income of two minimum wages or less. In this regard, it is need an effective $\mathrm{PHC}$ that helps the population to have access, especially those with higher socioeconomic need ${ }^{(3)}$. In this study was observed a high score for degree of affiliation, which may be related to the improvement of access to the services, the availability of professionals to assist the problems resolution and the interpersonal relationship with the users.

The satisfactory evaluation of longitudinality in the FHS reinforce that this care model make it possible to create a bond and interpersonal relationship between user and professional es aiming children and teenagers in the city of São Paulo, São Paulo State ${ }^{(20)}$, the FHS users had higher probability to consider longitudinality as proper in comparison with the traditional model. Another study carried out in the FHS of 11 cities of Minas Gerais State ${ }^{(21)}$, obtained positive results to the attribute in evaluations of the professionals and users.

The FHS has been playing its role of approaching user and family, and have potential to know people and understand them regarding their social, emotional and family context ${ }^{(3)}$. Whereas the traditional public service, often aiming health program and specific actions, are limited to a more curative care, which may make it more difficult to create bond and longitudinal care $^{(22)}$. In this regard, it was expected to obtain a low score for this attribute between the traditional care model, but not for the mixed model. The mixed care model does not have a care model defined, which may justify this result, thus not being recommended in the same health service to be practiced divergent care models.

Considering the range of the longitudinal care by the FHS, the results of this study reinforce this promising strategy expansion. The structural differences between the FHS and the other care models, such as users adscription, operation by generalist professional and community health agents in defined area can explain the difference of effectiveness between these health services. Therefore, to qualify the traditional model, would need to convert it into $\mathrm{FHS}^{(23)}$.

The multivariate analysis showed greater probability of longitudinality high score between people 65 years of age or more, in the health region of Entre Rios and among FHS users. Elderly users tend to create a relationship of stronger bond with the professional because they are more afflicted by chronic diseases that requires follow-ups, with more frequent visits to the PHC. Being a vulnerable population, the efforts taken to organize and do services pursuing values of equity are different ${ }^{(24)}$. Longitudinality obtained positive results in the FHS evaluation regarding to old people within a study conducted in a city of Natal region, Rio Grande do Norte State ${ }^{(24)}$ and in Porto Alegre, Rio Grande do Sul State ${ }^{(25)}$.

The association of the attribute with the age of respondents suggests that the longitudinal attention must be extended to 
the population with less than 60 years. These are possibly facing greater difficulties to access the $\mathrm{PHC}$, since the working hour often coincide with the business hour of these services. In this manner, it must be conformed the health services and actions to the conditions and needs of the local population.

The difference of the longitudinality score between the health regions Verdes Campos and Entre Rios is a unique discovery, as the two regions belong to the same RHCC. It is important to point out that the region Verdes Campos has a big city, which may adversely affects the longitudinality score of the region, since big urban areas present greater difficulties to restructure the primary care and to reorganize the care model ${ }^{(26)}$.

However, the FHS coverage by health region must be considered. In the research year, the region Verdes Campos had 435,021 thousand inhabitants and 52 units with the FHS care model, whereas the region Entre Rios had 124,477 thousand inhabitants and 32 units with the FHS care model ${ }^{(16-17)}$. In this scenario, considering to each FHS the maximum amount of population recommended by the Health Ministry ${ }^{(10)}$, this strategy coverage was $47.81 \%$ of the region Verdes Campos population and $100 \%$ in the Entre Rios, which might have helped the association of this region with the longitudinality high score.

The greater probability of longitudinality high score among FHS users reinforce the previously discussed results about the standard score differences of the attribute between the PHC models. In this way, the permanent evaluation of the FHS must be promoted, because its implementation is still in construction process in the country. In this context, it is highlighted the PCATool, a widely validated tool, which assess the PHC performance in different contexts, to identify aspects that require contributions to improve quality ${ }^{(27)}$.

\section{Study limitations}

This study has some limitations, including the sample selection that occurred by value judgment, consisting of the most accessible ones; in addition, the users were interviewed in the PHC units and might have given more positive answers because of possible reprisals in the health services. It is pointed out that the research outline does not allow making casual interferences of the results, only associations between the independent variables and the outcome. The study was conducted in a region of the Rio Grande do Sul State, thus the results generalization to other regions of the state or country is limited.

\section{Contributions to Nursing, health and public policy}

The results point to the importance of Health Care evaluation, representing a tool that subsidize the decision and plan process of policies and actions ${ }^{(18)}$. The longitudinality evaluation process, using the users, urge managers and professional to reconsider their own care practices and working process, committing them with the improvement do the PHC performance in the surveyed cities. In this context, it is pointed out nurse role importance in the longitudinal care creation, observing its performance with the users during the reception, the nursing appointment, the visit or the home care and the creation of actions to promote health and educate the users.

\section{CONCLUSION}

In this study, the PHC users show a high degree of affiliation with the service in all care models. In the longitudinality evaluation, the users scores better performance of the attribute in the FHS. This care model suggests better conditions for the longitudinality processing in relation to the traditional and mixed care model, even though, with scores distant from the maximum grades.

There are greater prevalence for the longitudinality high score at the age of 60 years or more, in the health region of housing Entre Rios and between FSH users. It proves that, to expand health actions from the old people to the other age groups and to extend the FHS coverage may be strategies to improve the longitudinality and the PHC quality. However, the expansion of health actions must consider the reality and needs of each population, promoting access to the services.

\section{FUNDING}

Master Scholarship of the Fundação de Amparo à Pesquisa do Estado do Rio Grande do Sul (FAPERGS). Financial support from the Conselho Nacional de Desenvolvimento Científico e Tecnológico (CNPq).

\section{REFERENCES}

1. Shi L. The impact of primary care: a focused review. Scientifica (Cairo) [Internet]. 2012 [cited 2017 Jan 10];2012:1-22. Available from: https://www.ncbi.nlm.nih.gov/pmc/articles/PMC3820521/

2. Starfield B. Atenção primária: equilíbrio entre necessidades de saúde, serviços e tecnologia. Brasília: UNESCO, Ministério da Saúde; 2002. 726 p.

3. Marin MJS, Marchioli M, Moracvick MYAD. Strengths and weaknesses of the care delivered in the traditional Primary Healthcare Units and Family Healthcare Strategy units in the perspective of users. Texto Contexto Enferm [Internet]. 2013 [cited 2017 Jan 10];22(3):780-8. Available from: http://www.scielo.br/pdf/tce/v22n3/en_v22n3a26.pdf

4. Brasil. Ministério da Saúde. Secretaria de Atenção em Saúde. Departamento de Atenção Básica. Manual do instrumento de avaliação da atenção primária à saúde: primary care assessment tool PACTool - Brasil. Brasília : Ministério da Saúde; 2010.80 p.

5. Harzheim E, Oliveira MMC, Agostinho MR, Hauser L, Stein AT, Gonçalves MR, et al. Validação do instrumento de avaliação da atenção primária à saúde: PCATool-Brasil adultos. Rev Bras Med Fam Comun[Internet]. 2013 [cited 2017 Jan 10];8(29):274-84. Available from: https://rbmfc.org.br/rbmfc/article/view/829/588 
6. Harzheim E, Pinto LF, Hauser L, Soranz D. Assessment of child and adult users of the degree of orientation of Primary Healthcare in the city of Rio de Janeiro, Brazil. Ciênc Saúde Colet[Internet]. 2016 [cited 2017 Jan 10];21(5):1399-408. Available from: http:// www.scielo.br/pdf/csc/v21n5/en_1413-8123-csc-21-05-1399.pdf

7. Kessler M, Eberhardt TD, Soares RSA, Signor E, Lima SBS, Weiller TH. Beneficios de la longitudinalidad como atributo de la Atención Primaria a Salud. Evidentia [Internet]. 2016 [cited 2017 May 23];13(53). Available from: http://www.index-f.com/ evidentia/n53/ev10182e.php

8. Paula CC, Silva CB, Nazário EG, Ferreira T, Schimith MD, Padoin SMM. Factors interfering with the atribute longitudinality in the primary health care: an integrative review. Rev Eletr Enf [Internet]. 2015 [cited 2017 May 23];17(4):1-11. Available from: https:// www.revistas.ufg.br/fen/article/viewFile/31084/20659

9. Oliveira MAC, Pereira IC. Atributos essenciais da Atenção Primária e a Estratégia Saúde da Família. Rev Bras Enferm [Internet]. 2013 [cited 2017 Jan 10];66(esp):158-64. Available from: http://www.scielo.br/pdf/reben/v66nspe/v66nspea20.pdf

10. Brasil. Ministério da Saúde. Secretaria de Atenção à Saúde. Departamento de Atenção Básica. Política Nacional de Atenção Básica. Brasília : Ministério da Saúde; 2012. 110 p.

11. Elias PE, Ferreira CW, Alves MCG, Cohn A, Kishima V, Escrivão Jr A, et al. Atenção Básica em Saúde: comparação entre PSF e UBS por estrato de exclusão social no município de São Paulo. Ciênc Saúde Colet[Internet]. 2006 [cited 2017 Jan 10];11(3):633-41. Available from: http://www.scielo.br/pdf/csc/v11n3/30979.pdf

12. Facchini LA, Piccini RX, Tomasi E, Thumé E, Silveira DS, Siqueira FV, et al. Desempenho do PSF no Sul e no Nordeste do Brasil: avaliação institucional e epidemiológica da Atenção Básica à Saúde. Ciênc Saúde Colet[Internet]. 2006 [cited 2017 Jan 10];11(3):669-81. Available from: http://www.scielo.br/pdf/csc/v11n3/30982.pdf

13. Chomatas E, Vigo A, Marty I, Hauser L, Harzheim E. Avaliação da presença e extensão dos atributos da atenção primária em Curitiba. Rev Bras Med Fam Comun[Internet]. 2013 [cited 2017 Jan 10];8(29):294-303. Available from: https://rbmfc.org.br/rbmfc/ article/view/828/587

14. Mendonça CS, Harzheim E, Duncan BB, Nunes LN, Leyh W. Trends in hospitalizations for primary care sensitive conditions following the implementation of Family Health Teams in Belo Horizonte, Brazil. Health Policy Plan [Internet]. 2012 [cited 2017 Jan 10];27(4):348-55. Available from: http://heapol.oxfordjournals.org/content/27/4/348.full.pdf + html

15. Brasil VP, Dias da Costa JS. Hospitalizações por condições sensíveis à atenção primária em Florianópolis, Santa Catarina - estudo ecológico de 2001 a 2011. Epidemiol Serv Saúde [Internet]. 2016 [cited 2017 Jan 10];25(1):75-84. Available from: http://www. scielo.br/pdf/ress/v25n1/2237-9622-ress-25-01-00075.pdf

16. Brasil. Ministério da Saúde. Histórico de Cobertura da Saúde da Família[Internet]. Rio Grande do Sul, 2015. [cited 2015 Jan 20]. Available from: http://dab.saude.gov.br/portaldab/historico_cobertura_sf.php

17. Brasil. Instituto Brasileiro de Geografia e Estatística (IBGE) [Internet]. Cidades@. Rio Grande do Sul. População estimada 2014. [cited 2015 Jan 20]. Available from: http://www.cidades.ibge.gov.br

18. Oliveira e Silva CS, Fonseca ADG, Souza e Souza LP, Siqueira LG, Belasco AGS, Barbosa DA. Integralidade e Atenção Primária à Saúde: avaliação sob a ótica dos usuários. Ciênc Saúde Colet [Internet]. 2014 [cited 2017 Jan 10];19(11):4407-15. Available from: http://www.scielosp.org/pdf/csc/v19n11/1413-8123-csc-19-11-4407.pdf

19. Nascimento L, Paula CC, Magnago TSBS, Padoin SMM, Harzheim E, Silva CB. Quality of Primary Health Care for children and adolescents living with HIV. Rev Latino-Am Enferm [Internet]. 2016 [cited 2017 Jan 10];24:e2720. Available from: http://www. scielo.br/pdf/rlae/v24/0104-1169-rlae-24-02720.pdf

20. Ferrer APS, Brentani AVM, Sucupira ACSL, Navega ACB, Cerqueira ES, Grisi SJFE. The effects of a people-centered model on longitudinally of care and utilization pattern of healthcare services: Brazilian evidence. Health Policy Plan [Internet]. 2014 [cited 2017 Jan 10];29(sup2):107-13. Available from: http://heapol.oxfordjournals.org/content/29/suppl 2/ii107.full.pdf + html

21. Silva AS, Baitelo TC, Fracolli LA. Avaliação da Atenção Primária à Saúde: a visão de usuários e profissionais sobre a Estratégia de Saúde da Família. Rev Latino-Am Enferm [Internet]. 2015 [cited 2017 Jan 10];23(5):979-87. Available from: http://www.scielo.br/ pdf/rlae/v23n5/pt_0104-1169-rlae-23-05-00979.pdf

22. Oliveira VBCA, Veríssimo MLÓR. Children's health care assistance according to their families: a comparison between models of Primary Care. Rev Esc Enferm USP [Internet]. 2015 [cited 2017 Jan 10];49(1):30-6. Available from: http://www.scielo.br/pdf/ reeusp/v49n1/0080-6234-reeusp-49-01-0030.pdf

23. Castro RCL, Knauth DR, Harzheim E, Hauser L, Duncan BB. Avaliação da qualidade da atenção primária pelos profissionais de saúde: comparação entre diferentes tipos de serviços. Cad Saúde Pública [Internet]. 2012 [cited 2017 Jan 10];28(9):1772-84. Available from: http://www.scielosp.org/pdf/csp/v28n9/v28n9a15.pdf

24. Araújo LUA, Gama ZAS, Nascimento FLA, Oliveira HFV, Azevedo WM, Almeida Júnior HJV. Avaliação da qualidade da atenção primária à saúde sob a perspectiva do idoso. Ciênc Saúde Colet [Internet]. 2014 [cited 2017 Jan 10];19(8):3521-32. Available from: http://www.scielo.br/pdf/csc/v19n8/1413-8123-csc-19-08-03521.pdf

25. Oliveira EB, Bozzetti MC, Hauser L, Duncan BB, Harzheim E. Avaliação da qualidade do cuidado a idosos nos serviços da rede pública de atenção primária à saúde de Porto Alegre, Brasil. Rev Bras Med Fam Comun[Internet]. 2013 [cited 2017 Jan 10];8(29):264-73. Available from: https://rbmfc.org.br/rbmfc/article/view/826/586 
26. Viana ALA, Rocha JSY, Elias PE, Ibañez N, Bousquat A. Atenção básica e dinâmica urbana nos grandes municípios paulistas, Brasil. Cad Saúde Pública [Internet]. 2008 [cited 2017 Jan 10];24(sup 1):79-90. Available from: http://www.scielo.br/pdf/csp/ v24s1/13.pdf

27. Turci MA, Lima-Costa MF, Macinko J. Influência de fatores estruturais e organizacionais no desempenho da atenção primária à saúde em Belo Horizonte, Minas Gerais, Brasil, na avaliação de gestores e enfermeiros. Cad Saúde Pública [Internet]. 2015 [cited 2017 Jan 10];31(9):1941-52. Available from: http://www.scielosp.org/pdf/csp/v31n9/0102-311X-csp-31-9-1941.pdf 